\title{
The Flattening Firm and Product Market Competition: The Effect of Trade Liberalization on Corporate Hierarchies
}

\author{
By Maria Guadalupe and Julie Wulf
}

\section{Online Appendix}

Table OA.1: Top 20 Industries with High U.S. Tariffs on Canadian Imports

The third column shows the tariff faced by firms in the sample and used in the analysis, averaged by industry (3 digit SIC).

\begin{tabular}{|c|c|c|}
\hline $\begin{array}{l}\text { US SIC } 87 \\
\text { (3-digit) }\end{array}$ & Industry Name & $\begin{array}{c}\text { U.S. Tariffs on Canadian } \\
\text { Imports } \\
\text { 1986-1988 Average } \\
\end{array}$ \\
\hline 302 & Rubber \& Plastics Footwear & $36.06 \%$ \\
\hline 233 & Women’s, Misses, Juniors Outerwear & $21.55 \%$ \\
\hline 211 & Cigarettes & $19.33 \%$ \\
\hline 225 & Knitting Mills & $16.81 \%$ \\
\hline 282 & $\begin{array}{l}\text { Plastics, Syn. Resins, Syn. Rubber, Cellulosic, Other } \\
\text { Fibers, Ex. Glass }\end{array}$ & $11.26 \%$ \\
\hline 202 & Dairy Products & $10.46 \%$ \\
\hline 314 & Footwear, Except Rubber & $10.01 \%$ \\
\hline 203 & Canned, Frozen, Preserved Fruit \& Vegetables & $9.76 \%$ \\
\hline 287 & Agricultural Chemicals & $9.76 \%$ \\
\hline 221 & Broadwoven Fabric Mills, Cotton & $8.81 \%$ \\
\hline 364 & Electric Lighting \& Wiring Equipment & $7.29 \%$ \\
\hline 201 & Meat Products & $7.16 \%$ \\
\hline 382 & $\begin{array}{l}\text { Lab. App., Analytical, Optical, Measuring \& } \\
\text { Controlling Instruments }\end{array}$ & $6.94 \%$ \\
\hline 208 & Beverages & $6.77 \%$ \\
\hline 366 & Telephone \& Telegraph Apparatus & $6.61 \%$ \\
\hline 375 & Motorcycles, Bicycles \& Parts & $6.38 \%$ \\
\hline 284 & $\begin{array}{l}\text { Soap, Detergent, Cleaning Preparation, Perfumes, } \\
\text { Cosmetics, \& Other }\end{array}$ & $6.13 \%$ \\
\hline 267 & $\begin{array}{l}\text { Converted Paper, Paperboard Products, Except } \\
\text { Boxes }\end{array}$ & $5.97 \%$ \\
\hline 329 & $\begin{array}{l}\text { Abrasive, Asbestos, Misc. Nonmetallic Mineral } \\
\text { Products }\end{array}$ & $5.83 \%$ \\
\hline 384 & Surgical, Medical, \& Dental Instruments \& Supplies & $5.72 \%$ \\
\hline
\end{tabular}


Table OA.2: Examples of Canadian Companies in High Tariff Industries

\begin{tabular}{|c|c|c|c|}
\hline $\begin{array}{l}\text { US SIC } 87 \\
\text { (3-digit) }\end{array}$ & Industry Name & $\begin{array}{c}\text { U.S. Tariffs on } \\
\text { Canadian Imports } \\
\text { 1986-1988 Average }\end{array}$ & $\begin{array}{c}\text { Examples of Canadian } \\
\text { Companies } \\
\text { (Sales in U.S. \$) }\end{array}$ \\
\hline 211 & Cigarettes & $19.33 \%$ & $\begin{array}{l}\text { Imperial Tobacco ( } \$ 4.2 \text { b) } \\
\text { Rothman’s }(\$ 400 \mathrm{~m})\end{array}$ \\
\hline 225 & Knitting Mills & $16.81 \%$ & Dominion Textiles ( $\$ 1.4$ b) \\
\hline 282 & $\begin{array}{l}\text { Plastics, Syn. Resins, Syn. } \\
\text { Rubber, Cellulosic, Other } \\
\text { Fibers, Ex. Glass }\end{array}$ & $11.26 \%$ & Nova Chemicals ( $\$ 4.8$ b) \\
\hline 208 & Beverages & $6.77 \%$ & $\begin{array}{l}\text { Seagram }(\$ 4.5 \mathrm{~b}) \\
\text { Molson }(\$ 2.1 \mathrm{~b})\end{array}$ \\
\hline 366 & $\begin{array}{l}\text { Telephone \& Telegraph } \\
\text { Apparatus }\end{array}$ & $6.61 \%$ & Nortel Networks (\$6.1 b) \\
\hline
\end{tabular}


Table OA.3: Evidence for Effect of FTA

\begin{tabular}{|c|c|c|c|c|c|}
\hline & \multicolumn{5}{|c|}{ Panel A: Division Depth } \\
\hline & $\begin{array}{c}\text { Div.Depth } \\
\text { Canada> ROW } \\
\text { Tariff }\end{array}$ & $\begin{array}{c}\text { Div.Depth } \\
\text { Canada }>\text { ROW Tariff } \\
4 \text { digit }\end{array}$ & $\begin{array}{l}\text { Div.Depth } \\
\text { Fast tariff } \\
\text { reduction }\end{array}$ & $\begin{array}{l}\text { Div.Depth } \\
\text { Incl. Serv. }\end{array}$ & Div.Depth \\
\hline & 1a & $2 \mathrm{a}$ & За & $4 a$ & $5 a$ \\
\hline AvT89*Post89 & $\begin{array}{c}-5.523 \\
{[2.504]^{* *}}\end{array}$ & $\begin{array}{c}-12.019 \\
{[3.565]^{* * * *}}\end{array}$ & $\begin{array}{c}-5.491 \\
{[1.245]^{* * *}}\end{array}$ & $\begin{array}{c}-3.21 \\
{[1.248]^{* *}}\end{array}$ & $\begin{array}{c}-3.398 \\
{[1.259]^{* * *}}\end{array}$ \\
\hline Exch.Rate*OriginImp.Pen. & & & & & $\begin{array}{c}0.806 \\
{[1.190]}\end{array}$ \\
\hline Division FE & yes & yes & yes & Yes & yes \\
\hline Division trends & yes & yes & yes & Yes & yes \\
\hline Observations & 2962 & 1545 & 1697 & 6965 & 5702 \\
\hline \multirow[t]{4}{*}{ R-squared } & 0.04 & 0.08 & 0.084 & 0.023 & 0.032 \\
\hline & \multicolumn{5}{|c|}{ Panel B: CEO Span of control } \\
\hline & $\begin{array}{c}\text { CEO Span } \\
\text { Canada }>\text { ROW tariff }\end{array}$ & $\begin{array}{c}\text { CEO Span } \\
\text { Canada }>\text { ROW tariff } \\
4 \text { digit }\end{array}$ & $\begin{array}{l}\text { CEO Span } \\
\text { Fast tariff } \\
\text { Reduction }\end{array}$ & $\begin{array}{l}\text { CEO Span } \\
\text { Incl. Serv. }\end{array}$ & CEO Span \\
\hline & $1 \mathrm{~b}$ & $2 b$ & $3 b$ & $4 \mathrm{~b}$ & $5 b$ \\
\hline AvT89*Post89 & 18.137 & 23.466 & 5.648 & 7.545 & 10.453 \\
\hline Exch.Rate*OriginImp.Pen. & {$[10.504]^{*}$} & {$[6.351]^{* * *}$} & [6.926] & {$[4.025]^{*}$} & $\begin{array}{c}{[4.155]^{* *}} \\
4.649 \\
{[7.736]}\end{array}$ \\
\hline Firm FE & Yes & yes & yes & Yes & yes \\
\hline Firm trends & Yes & yes & yes & Yes & yes \\
\hline Observations & 1073 & 512 & 531 & 2711 & 1962 \\
\hline R-squared & 0.03 & 0.07 & 0.059 & 0.019 & 0.021 \\
\hline
\end{tabular}

Notes: Std. Errors in brackets, clustered by industry (SIC4). All regressions include year dummies. All regressions also include the interaction of Post89 with US industry skill intensity, capital intensity and TFP growth pre-89 to account for tariff endogeneity (except col. 4 because these are not available for services industries), as well as $\ln$ firm sales and ln division employment. Div Depth is the number of managers between the DM and the CEO. AvT89 is the average US tariff rate on Canadian imports in 86-88, by industry. Exch.Rate*OriginImp.Pen is the bilateral Canada U.S. dollar exchange rate multiplied by the level of import penetration of the industry in 1988, Source: IMFIFS and Bernard et al. (2006). Columns 1 and 2 restrict the sample to firms in industries with US tariffs on Canadian imports above the average tariff on imports from the rest of the world; col. 3 restricts the sample to firms in industries with the fastest scheduled tariff reductions (that had experienced at least $60 \%$ tariff reductions from their original level by 1994); col. 4 also includes services firms in the estimation, with AvT89=0; col. 5 includes the interaction of the Canada-US exchange rate and the level of import penetration in the industry before 1989. 
Table OA.3: Robustness Checks for the Effect of the FTA on Hierarchies

Overall, the paper find systematic evidence that firms experiencing a larger shock following the trade liberalization (those in more protected industries prior to 1989) reduced division depth and increased CEO span of control more relative to firms less affected by the liberalization. While this effect is robust to a number of specifications, one might still question whether the liberalization with Canada was important to U.S. firms. In Table OA.3, we provide additional evidence that further supports our claim that the trade liberalization led U.S. manufacturing firms to flatten. All regressions replicate the specification of column 2 onwards in Tables 2 (division depth) and 3 (CEO span) in the paper and include firm/ division fixed effects and trends. The table shows that the effect of the FTA is larger in industries in which the cost of importing Canadian goods into the U.S. is higher relative to that for the rest of the world (columns 1 and 2). One should expect that tariff reductions will lead to greater competition and a bigger effect on flattening in industries where the US tariff on Canadian imports is higher than the rest of the world (ROW) tariff. Why? If the US tariff in an industry is above the ROW tariff, the cost of imports from Canada would decline by more relative to the cost in an industry with tariffs below the ROW tariff. We find the sub-sample of firms in industries that faced larger US tariff in comparison to the ROW tariff do flatten more.

The effect is also larger in industries in which the scheduled tariff reduction is faster (column 3). Our results are robust when we include service industry firms as the main control group, with an assigned tariff (AvT) of zero (column 4). This mitigates concerns that all we are capturing is a spurious trend. Finally, the results are also unchanged when we control for exchange rate fluctuations that may differentially affect industries with different levels of import penetration (column 5) 